\section{Democracy, Oratory, and the Rise of Historiography in Fifth-century}

Greece

JONAS GRETHLEIN

Historiography did not emerge in Greece until the second half of the fifth century. While the past had been and continued to be the object of epics, elegy, tragedy, and oratory, prose accounts that focused on the human past were a late development. Recently, scholars have challenged Jacoby's influential thesis that Herodotus was the pater historiae (Fowler 1996; Porciani 2001), but even if some authors wrote the pater historiae (Fowler 1996; Porciani 2001), but even if some authors wot
prose accounts before him, his Histories and Thucydides' History are the only fully preserved historiographical works from the fifth century and therefore our most important evidence for the rise of Greek historiography. Although neither called himself "historian," they laid the foundation of the new genre.

himself "historian," they laid the foundation or the new genre.

Christian Meier (1980:360-434; 1987) argued that the rise of historiography was closely linked to the emergence of democracy, not least because both are based on the turn from the "nomistic" to the "cratistic" epoch. Brilliant though his argument is, many points should alert us to be very careful with such a sweeping thesis. ${ }^{2}$ The very distinction between "nomistic" and "cratistic" is vulnerable to thesiections from many directions. I also doubt that the rise of historiography can be explained sufficiently as a response to the need for orientation that resulted from the the polis' social and political life. It is important to note that Athenian democracy, with all its institutions, established something new but "isonomic" (egalitarian) structures that required citizens to be active and well-informed reached back much farther ${ }^{3}$ the of historiography, can be found much earlier too. ${ }^{4}$

The Greek Polis and the Invention of Democracy: A Politico-cultural Transfornation and It Jnterpretations, First Edition. Edited by Johann P. Arnason, Kurt A. Raaflaub, and Peter Wagner C 2013 John Wiley \& Sons, Inc. Publishcd 2013 by John Wiley \& Sons, Inc.
Even so, I still believe that it is fruitful to examine the rise of historiography against the backdrop of democracy. The most obvious approach would be to investigate Herodotus's and Thucydides' comments on democratic Athens. ${ }^{5}$ In this tigate Herodoth chapter, I will purse anoher path and reconsider te relation betwen historians and democracy by examining their attitudes towards oratory. Oratory forms an interesting link between democracy and historiography. Needless to say, the art of speaking long preceded the fifth century (Kennedy 1963: ch.2), but say, the art of speaking long preceded the fld of democracy with its assemblies and rhetoric played a crucial role in the world of democracy wh the primary genre law-courts (Lanni, this vol.). At the same time, oratory was the primary genre besides poetry in which the Greeks encountered their past. The funeral oration (epitaphioi logoi) came close to representing something like the "official history" (epilapbioi lon in deliberative speeches past exempla and narratives figured very prominently. ${ }^{6}$ Therefore oratory was one of the commemorative genres against which the first historians had to define their new approach to the past. Their stand on oratory, I suggest, reveals an ambiguous relation between historiography and democracy.

I will start, against the chronological order, with Thucydides, since he criticizes oratory both implicitly and explicitly (I). Herodotus does not explicitly set himself off against orators, but the Histories contain an implicit critique of the use of the past in speeches (II). While Thucydides' and Herodotus's deconstruction of paeches indicates a critical attitude towards democracy, I will argue that the very foech of their criticism has democratic features. An interesting parallel for this tension between content and form is afforded by Plato (III)

\section{I}

In a first step, I will revisit Thucydides' reflection on method which, I propose, m a first the polemic is reinforced by an implicit criticism which is illustrated by Pericles' funcral speech (b).

(a) Unlike Herodotus, Thucydides provides his readers at the beginning of his History with an explicit reflection on his method. In what is often dubbed as "method chapter" he dissociates his work from the accounts of pocts and logographoi: while he scrutinizes the evidence available and takes pains to find the logographo $i$ : while he scrutinizes the evidence avalable and take truth, the poets "adorn" their praise "with exaggerations" and logographoi present untrustworthy accounts (1 2 a Homer. Newly published fragments from Simonides' Plataea-elegy have prompted Deborah Boedeker (1995: 226-9) to Simonides' Plataea-elegy have prompted Deborah Boedek (hiticism also applies to other poetic accounts of the past, such as elegies. But what about logographoi? Most scholars tended to follow Georg Friedrich Creuzer's argument (1845; see also Lipsius 1886) that lographos is a technical term for the pre-Herodotean historians mentioned by logographos is a technical the first-century historian and literary critic Dionysius of Halicarnassus (De Thuo. 5 ). Yet the existence of such historians has been questioned by Felix Jacoby and 
others. Moreover there is no evidence for such a meaning of logographos The present communis opinio therefore assumes that logographos means "proseauthor" and that Thucydides is taking a stand against Herodotus and other contemporary historians.

This view, however, also has serious flaws. A look at all the uses of logographos in fifth- and fourth-century literature reveals that there is not a single passage where logographos can be safely assumed to mean "prose-author" (Grethlein 2004). Its conventional meaning is "speech-writer" or "orator." Given that oratory was an important commemorative genre, this meaning makes perfect sense for our passage in Thucydides, and there is no reason whatsoever to insist on a new and unprecedented meaning of the word.

Moreover, the meaning "orator" is supported by the context. Thucydides reproaches the logographoi for telling stories that are mythodess. This word has been widely translated as "romance" or "fairy-tale," but Stewart Flory (1990) argues compellingly that it means "flattering" and that in Thucydides it signifies patriotic stories. Obviously, this criticism cannot be directed at Herodotus, who has a rather pan-Hellenic perspective, but it could very well apply to oratory. In both epideictic and deliberative speeches, the past is tainted by a patriotic slant.

Thucydides' rejection of a "competition prize to be heard only for the moment" (agōnisma es to parachrēma akonein) could refer to recitations of historical narratives (logoi) as they are attested for Herodotus. Yet, the criticism of agonisma applies even better to oratory. Speeches are often called agōnes (competition pieces) in classical literature and we find this use even in the History. ${ }^{8}$ Moreover, Thucydides criticizes that the logographoi are "attractive to listen to" (prosagogos). The same and related words describe the effect of speeches in several passages in Thucydides (Grethlein 2005: 57 with n.73).

Both lexical evidence and the semantics of the context thus clearly favor the meaning "orator" for logographos in Thucydides. Thucydides' criticism addresses not poets and prose-authors such as Herodotus, but poets and orators. And indeed, as I have noted, poetry and oratory were the most important media of commemoration in comparison to which Thucydides had to define his own approach to the past. It is difficult to assess how many prose accounts of the past were being written at the end of the fifth century but it is a fair guess that they had not yet reached enough relevance to compete with poetry and oratory.

(b) Thucydides enhances his explicit reflection on oratory by a form of implicit criticism. Some specches, I would like to argue, are embedded in the History in order to serve as a foil for it. ${ }^{9}$ The example that I am going to discuss here is the famous epitaphios logos of Pericles. ${ }^{10}$ This speech figures in the History as an alternative commemorative medium that throws into relief the superiority of Thucydides' new approach to the past.

Pericles' speech contains striking echoes of Thucydides' own methodical reflec-


our praises nor any other whose verses will charm (terpsei) for the moment antika) and whose claims the factual truth will destroy" (2.41.4). Not only does (to a utika) and whose clacidides' criticism of poets (1.21.1) but even the wording this correspond to Thucydion in 1.22.4: "And the results, by avoiding patriotic storecalls Thucydides' reflection in rytelling, will perhaps seem less enjoyable (euterpesteron) for for moment (es to possession for all time, not a competitio

Like Thucydides, Pericles blames the poets for not caring about the truth and Like Thucydides, in contrast claims to offer a truthful account himse fallen (2.43.2) corresponds The immortal glory that Pericles bestows onto the fallen $(2.43 .2)$ corresponds to Thucydides" "possession for all time" (ktêma es aiei, 1.22.4). I could adduce to thereby establish a further comments that resember Funeral Oration and the History (see Grethlein correspondence between the Funeral Oration and the Histor that mark crucial 2005: 43-6). It is time, however, to turn to passages that mark crucial differences.

To start with, Pericles refers to his speech as "praise" (bymnein), the very activity To start with, Pericles refers to his speech as : "For it is their virtues, and those of that Thucydides blames the poets for (2.42.2): "For it is their men like them, that have adorned the qualities I have praised ( city." In his criticism of the poets, Thucydides states (1.21.1): "In light of the evidence I have cited, however, no one would go wrong in supposing that the early events I have related happened much in that way: not believing that the past was events I have relat poets have sung in their praise (bymnèkasi), adorning it with more like what the poet

(terpsei) Moreover, Pericles first reprimands "and he but later he that his speech also conveys terpsi for the moment" (2.41.4), but laticles' criticism of the poets not only evoke (2.44.4). It is striking that Pericles' criticism of the porbes his own speech in Thucydides' methodical reflections, but that he also describes his own speech in the same terms that Thucydides uses to question poetic accounts of the past. At first glance, the echoes establish a similarity between History and funeral speech; a first glance, the echoes estaber reveals that the echoes rather call the readers' attention closer inspection, however.

out himself the mefore Pe epitaphioi logoi. He he sets out to deliver his speech, he presents a crical ve fulfilling the audience's is worried about the necessity inherent in this genre of fuly neglected by scholars, expectations (2.35). This concern, which has been strangely neglected by schollesents reveals a major difference between speeches and the History and presents the key to their juxtaposition: while the funeral speeches are oriented toward the listeners' expectations, Thucydides claims that the gauge for his account is the truth $(1.20 .3,21.1)$.

Given rhetoric's prominence as a commemorative genre, the echoes of Thucydides' reflections and Pericles' explicit criticism suggest a meta-poetic or neta-historical function for Pericles' funeral speech. It is embedded in the History meta-historical function for Pericles' fun the past. The deficiencies of epideictic as a foil for Thucydides' own approach to the past. The defies' rigorous claims. rhetoric are underscored by the evocation of Thucydides
Thucydides' account, on the other hand, is thrown into relief by the epitaphios 
logos - which, therefore implicitly continues and reinforces the explicit polemic against orators in the methodological reflections of the first book.

Thucydides thereby calls into question an important institution of democratic Athens. As Nicole Loraux has shown (1986), the epitaphios logos was not only an epideictic genre, but also a crucial medium of defining the identity of the Athenian polis. While the particular occasion and the mourning of the dead are given short shrift, Athens' glorious past and its eternal values figure prominently. Repeated year for year in front of major audiences, the funeral speeches' flattering portrayal of Athens in past and present must have had quite an influence on how the Athenians perceived themselves.

What is more, the very shortcoming of the epitaphios logos that is unveiled by Pericles' introductory reflection and by the juxtaposition with the History plays a crucial role in Athens' downfall. In 2.65, Thucydides points out that under Pericles' guidance Athens fared well, but that his successors brought ruin over it. ${ }^{11}$ He says of Pericles, that he was

influential through both reputation and judgment and notable for being most resistant to bribery, exercised free control over the people and was not led by them instead
of leading them, because he did not speak to please in order to acquire power by of leading them, because he did not speak to please in order to acquire power by
improper means but, since he had this through his prestige, even contradicted them improper means but, since he had this through his prestige, even contradicted them in their anger... Those who came later, in contrast, since they were more on an equal level with one another and each was striving to become the first, even resorted to handing over affairs to the people's pleasure $(2.65 .8-10)$.

The speakers' inclination to meet the expectations of their audience proves most detrimental in the history of Athens. Not only does Thucydides' critique of oratory draw attention to a fundamental flaw of democracy, but the juxtaposition of the epitaphios logos with the History underscores the political relevance of his own approach. As the digressions on the Sicilian archaeology and the tyrannicide reveal, the solid historical knowledge that Thucydides presents would have prevented Athens from great disasters. Only their ignorance of the Sicilian past and its present condition made the Athenians undertake the Sicilian expedition, and wrong beliefs about the tyrants created the explosive atmosphere of a witch-hunt in $415 .^{12}$ Thus, besides offering a critique of democratic politics, Thucydides indicates that such politics would benefit from his rigid methodology.

\section{II}

As I have pointed out, Thucydides could not rely on an established tradition of genre. Yet he was not the first Greek to write a prose account of the past. A couple of other authors did so at the end of the fifth century, most prominently Herodotus. Thucydides never mentions him by name but the History of the Peloponnesian War seems to have been written with Herodotus's Histories as a backdrop. ${ }^{13}$ Does
Herodotus already juxtapose his work with oratory? Do the Histories have a politica tone that is as strong as that of the History?

On first reflection, the answer is no. Herodotus engages in critical discussions of Homer (2.112-20), but he does not explicitly criticize oratory. Because his focus is directed at a more distant past and he is thematically much broader than Thucydides, politics figures less prominently in his work. However, I would like to demonstrate that Herodotus nonetheless also casts a critical eye on speeches, and that, although he does not juxtapose his approach with oratory, his criticism of oratory is linked to democracy and to recent political events. In another paper (Grethlein 2006), I made a similar argument for the Syracusan embassy scen (7.153-63); here, I will turn to the speech duel between the Tegeans and Athenians Platea (see Solmsen 1944. Pallantza 2005: 167-8; Boedeker 2012: 18-23)

Before the battle of Plataea in 479 , Herodotus has the Tegeans and Athenians get into an argument over the battle formation. ${ }^{14}$ The Spartans, it is agreed, can choose their wing, but both the Athenians and the Tegeans lay claim to the other wing. Instead of simply reporting who prevails, Herodotus lets both parties give speeches..$^{15}$ I will first outline the speeches and discuss the immanent criticism of their historical arguments (a). I will then argue that this deconstruction applies to essential creeds of democratic Athens (b). Finally, I will point out that event beyond the work's historical framework are evoked in the speeches and their context. Hence Herodotus's critique of how rhetoric utilizes the past also refers to recent or even contemporary politics (c)

(a) The Tegeans argue that they have always enjoyed a privileged position (9.26.2-7). When the sons of Heracles tried to invade the Peloponnese, the Peloponnesians gathered at the Isthmus to defend their land. Hyllus suggested a duel between himself and the best of the Peloponnesians. In the case of his victory, the Heraclidae would be allowed to settle in the area; was his opponent to win, the Heraclidae would be barred from the Peloponnese for one hundred years. In the event, the Tegean king Echemus killed Hyllus and thus the Spartans were unable to settle in the Peloponnese for one hundred years. From that time, the Tegeans claim, they enjoyed special honors. Echemus not only serves as evidence for the Tegeans' excellence, he also offers a parallel to the present situation. In their attempt to conquer Greece, the Persians resemble the Heraclidae who tried to invade the Peloponnese. Like the ancient Peloponnesians who faced the sons of Heracles, the present residents of the peninsula gathered at the Isthmus and only hesitantly joined the Athenian forces outside their own land.

In their reply to this speech (9.27), the Athenians first question the whole discussion by pointing out that mere words hardly matter when deeds are required. Nevertheless, they also conjure up an entire catalog of achievements of their own: they defended the Heraclidae against their father's nemesis, Eurystheus, helped the Argives to bury their dead after their disastrous defeat at Thebes, fought off the Amazons, and outshone everyone at Troy. However, the Athenians add, such ancient events do not count for much - who was strong in the past can now be weak, and vice versa. They therefore refer to their victory at Marathon, a recent 
display of virtue. Despite offering such compelling evidence of their excellence they agree to fight in any position the Spartans may choose for them.

At first glance, the Athenians' rejection of ancient deeds is merely a rhetorical device to highlight their strongest point, Marathon. ${ }^{16}$ In fact, despite their criti cism, the Athenians do not miss the opportunity to elaborate on a whole series of ancient achievements, and this criticism, even if only used as a rhetorical device echoes the end of the Histories' proem and thereby prompts the reader to reflect on the use of mythical exempla in speeches (1.5.4): "For most of those [i.e., cities] which were great once are small today; and those which used to be small were great in my own time. Knowing, therefore, that human prosperity never abides long in the same place, I shall pay attention to both alike."

The resonance of this central authorial statement in that of the Athenians gives the latter a weight that goes beyond its rhetorical function within their speech and draws the reader's attention to a general flaw of exemplary uses of the past: such uses presuppose that the present resembles the past, and this assumption does not square with the Histories' emphasis on chance and change. Only in the case of Marathon, a recent exemplum, the past is able to legitimize the present. ${ }^{17}$

(b) The exemplary use of the past that the speech duel at Plataea implicitly chal lenges is essential for historical arguments in speeches. Time and again, Greek ora tors adduce parallels from the past to buttress their present assertions. ${ }^{18}$ Ye Herodotus's criticism not only deconstructs rhetorical arguments in general but is also levelled at central creeds of Athenian democracy. As scholars have not failed to note, the Athenian speech emphasizes central topoi of the epitaphioi logoi. ${ }^{19}$ Assisting the Heraclidae, supporting the Argives, fighting against the Amazons, and defeating the Persians at Marathon: these episodes form the core of the "historical" sections in funeral speeches. The usual order is here changed, giving prominence to the intervention in favor of the Heraclidae which responds directly to the claim the Tegeans derive from Echemus's victory over the Heracles-son Hyllus. ${ }^{20}$ While it is true that "praises of Athens must surely have been made before the formal introduction of a 'funeral speech', and the sorts of praises used here by the Athenians are familiar from some parts of tragedy" (Flower and Marincola 2002: ad 9.27.1-6), it is striking that the list of deeds follows the catalog of the epitaphioi logoi so closely. ${ }^{21}$

Moreover, the question arises of how relevant some of these exempla are for the Athenians' case. The Heraclidae-story counters the Tegean exemplum, and the attack of the Amazons may prefigure the Persian invasion, ${ }^{22}$ but there is no particular reason why the support of the Argives should be mentioned here. Like that of the Heraclidae, this myth not only propagated another polis' obligation towards Athens but helped disguise an aggressive foreign policy as selfless help to others (Neumann 1995: 149-67). Thus it does not really fit into an argument made by Athenians who have no claim to hegemony yet. Of course, the story of the Argives could serve here merely to reflect Athenian boasting, and I would not go so far as to call it anachronistic in this context, but one has the impression

of a slight displacement, and this reinforces the reference to the tradition of funeral speeches. ${ }^{23}$ There is no doubt that the Athenian speech would have reminded Herodotus's readers of the epitapbios logos.

Hence, although at the level of the action Herodotus's statement may be no more than a rhetorical device, its subversive potential arguably reaches quite far: it challenges not only the exemplary use of the past that is so prominent in Athenian speeches throughout but also affects the genre that helped "invent" Athens (Loraux 1986). In undermining the relevance of topor that were central in the funeral speeches, the Athenians' own words question an institution that played an important role in defining their political identity

(c) Herodotus's implicit critique of historical arguments gains a further dimension by foreshadowing the future history of Athens. In the Syracusan embassy scene the main characters' use of the past is questionable precisely because their claims to leadership that are supported by the invocation of a heroic past point forward to the later intra-Hellenic fights for hegemony (Grethlein 2006). Similar anticipation of the future can be found in the debate between the Tegeans and Athenians. As we have seen, the catalogue of deeds familiar from the epitapbioi logoi and bearing the imprint of Athenian imperialism jolts the readers to think of a later time when Athens had to justify its aggressive foreign policy. Moreover, the controversy between Athenians and Tegeans centers on terms such as beggemonia and stasis that gained special force in the later fifth century and thus adumbrates the conflicts to come. ${ }^{24}$ For now, the Athenians yield to t Spartans and engage only in a verbal contest with the Tegeans, but ve they will develop claims that will lead to serious tensions and bitte Hdt. 8.3). The term othismos ("thrusting, pushing") that Herodo verbal duel is more than a metaphor; playing a role in hoplite f: towards future martial encounters.

The significance of the speech duel is further reinfor

ipations in the subsequent battle at Plataea. For $c$ who excelled beyond others in that battle ? prompts Herodotus to speak about that abducted and hidden Helen, her b threatened to destroy everything or some other Deceleans, Attica's fate, revealed t'

Sparta has ever $\sin r$

seats at public functi

between Athens and Sp. unharmed." 25

In a zigzag course, the 1 prompts Herodotus to turn tc past. A far-reaching flashback lei rator's present. Since the Deceleal the historian arguably introduced it Dia myth a link with the Peloponnesia 
funeral speeches. ${ }^{23}$ There is no doubt that the Athenian speech would have reminded Herodotus's readers of the epitaphios logos.

Hence, although at the level of the action Herodotus's statement may be no more than a rhetorical device, its subversive potential arguably reaches quite far: it challenges not only the exemplary use of the past that is so prominent in Athenian speeches throughout but also affects the genre that helped "invent" Athens (Loraux 1986). In undermining the relevance of topoi that were central in the funeral speeches, the Athenians' own words question an institution that played an important role in defining their political identity.

(c) Herodotus's implicit critique of historical arguments gains a further dimension by foreshadowing the future history of Athens. In the Syracusan embassy scene the main characters' use of the past is questionable precisely because their claims to leadership that are supported by the invocation of a heroic past point forward to the later intra-Hellenic fights for hegemony (Grethlein 2006). Similar anticipation of the future can be found in the debate between the Tegeans and Athenians. As we have seen, the catalogue of deeds familiar from the epitaphioi logoi and bearing the imprint of Athenian imperialism jolts the readers to think of a later time when Athens had to justify its aggressive foreign policy. Moreover, the controversy between Athenians and Tegeans centers on terms such as hegemonia and stasis that gained special force in the later fifth century, and thus adumbrates the conflicts to come. ${ }^{24}$ For now, the Athenians yield to the Spartans and engage only in a verbal contest with the Tegeans, but very soon they will develop claims that will lead to serious tensions and bitter fights (see Hdt. 8.3). The term othismos ("thrusting, pushing") that Herodotus uses for the verbal duel is more than a metaphor; playing a role in hoplite fighting, it gestures towards future martial encounters.

The significance of the speech duel is further reinforced by a dense net of anticipations in the subsequent battle at Plataea. For example, Sophanes, the Athenian who excelled beyond others in that battle (9.73), came from Decelea, which prompts Herodotus to speak about that place's mythic past. After Theseus had abducted and hidden Helen, her brothers, the Tyndarids, invaded Attica and threatened to destroy everything they encountered in their search for her. Decelus or some other Deceleans, angered by Theseus's hybris and concerned about Attica's fate, revealed that Helen was in Aphidna. "In return for this service, Sparta has ever since given the Deceleans the freedom of their city and special seats at public functions - so that during the war, many years after these events between Athens and Sparta, the Spartans in their raids on Attica always left Decelea unharmed." 25

In a zigzag course, the local affiliation of Sophanes, who excelled at Plataea, prompts Herodotus to turn to myth and then to bounce right back to the recent past. A far-reaching flashback leads to a foreshadowing of events close to the narrator's present. Since the Decelean origin of Sophanes is irrelevant in its context, the historian arguably introduced it there precisely for the purpose of establishing pia myth a link with the Peloponnesian War. 
Flower and Marincola even suggest that the story of Theseus offers not only an explanation for the saving of Decelea but, more broadly, serves as a mirror for the Peloponnesian War as a whole:

The hybris of Theseus here in provoking a Spartan invasion may allude to Athens' (or Pericles'?) role in the outbreak of the Peloponnesian War. Decelus, we are next told, revealed Helen's whereabouts because 'he feared for the whole land of Attica'. In Alcman's version of this myth (Paus. $1.41 .4=P M G 21$ ) the Dioscuri actually captured Athens; by not accepting that version $\mathrm{H}$. is perhaps providing contemporary Athenians with a mythic paradigm for preserving their city in the current war: by following the example of Decelus and coming to terms with Sparta, they could still save themselves from destruction. ${ }^{26}$

The nod to the Peloponnesian War reinforces the foreshadowing of later intraHellenic conflicts in the speech duel between the Athenians and Tegeans. The arguments of the Athenians at Plataea that now figure in a quarrel over positions in a battle formation were to become important tools in later and fierce fights for hegemony. At the end of the Histories, a net of allusions to the future suggests that Athens will follow Persia in the cycle of empires that rise and then fall due to their rulers' hybris. ${ }^{27}$ The deconstruction of historical arguments is thus closely linked to a critique of the aggressive policy that Athens was to pursue after the Persian Wars. It is worth noting that an imperialist foreign policy was ranking high on the agenda of "radical" democrats, while "conservative" forces would have preferred a more cautious course.

Perhaps Herodotus's critique even derives particular significance from being linked to Plataea. The foreshadowing points to a time when the battle of Plataea had itself acquired high symbolic capital. ${ }^{28} \mathrm{As}$, for example, the Plataean Debate in Thucydides reveals (Grethlein 2012), the heritage of Plataea was fiercely contested. This gives Herodotus's speech duel at Plataea an additional twist: the use of the past for legitimizing purposes is questioned in the context of an event that itself served to buttress claims in Herodotus's time. In a way, therefore, the battle of Plataia entails in nuce the history of its own reception.

\section{III}

While both Herodotus and Thucydides betray a critical attitude toward speeches, it is important not to overlook two crucial differences. Thucydides' deconstruction of speeches complements an explicit polemic against oratory. In Herodotus, on the other hand, such critique is only implicit. Moreover, Thucydides alerts his readers to the detrimental impact of rhetoric on decision-making, while Herodotus questions the rhetorical use of historical arguments in order to criticize Athens' foreign policy. And yet, despite the differences in explicitness and purpose, in both cases the deconstruction of speeches reveals a critique of Athens' democracy.
Yet again, these early historiographical works are not as different from rhetorical Yet again, these early historiogiaphea work thetus and Thucydides are accounts as they would make us believe. Both Herodotical devices. To give an briliant narrators, and their narratives are full of rhetorical devices. To give an obvious example, Thucydides rejects the agönisma (competitiveness) of speeches A the same time, he goes out of his way to emphasize the greatness of "his" war At the same time, he goes out of his wars, and thereby enters a competition with compared to the Trojan and Persian

Homer and Herodotus. Even the rejection of rhetoric can be rhetorical. More importanthing directly to democracy, at least has some affinity with it. This even if it owes nothing difupport, just as it is a challenge to determine what narrative argument is difficult to support, jus as it is a the openness of Histories and forms are democratic. Yet it can be argued that the openness of Histories and History corresponds to the openness of democratic procedure

similarity with literary genres that are considered democratic. Both Herodotus and Thucydides composed polyphonous texts. Not only do the readers encounter various voices but time and again ambiguities prompt then to ponder different, often even opposite aspects. Much that is of great importance is not mentioned explicitly, but instead the text incites readers to engage in constructing meaning themselves. ${ }^{30}$ Of course, already in the epics we find complex structing meaning themselves. texts that elude simple explafinity with democratic procedures that do not rely on goes deeper and shows an affinity with democratic procednes the reader in the authority but require negotiation. The strong engagement of the reader in the construction of meaning in history corresponds to the involvement of the citizen in the Athenian democracy.

At first sight, this may sound rather abstract but historiography's affinity with emocracy can also be illustrated on a more concrete level. In the assembly or law diven che readers of the Histories are in make decisions based on what they hencounter diverging accounts, only some a very sinular sithe of which Herodotus bothers to assess himself. In other cases, the readers have to weigh different options by themselves. Thucydides presents a much more linear account than Herodotus, but one of the most typical devices of his narrative is the account than Herodots paring of speeches. Without the hemp (Conno must compare and judge the contrasting positions prent 1984; Morrison 1999). Are the Plataeans or Thebans right (3.52-68)? Diodotu gets the better of Cleon $(3.36-49)$, but are his arguments really superior? In analogy gets the better of Cleon $(3.36-49$, to democratic procedures, Histories and Historic citizens, the readers have to form thei obvious evalua

Such openness and polyphony move Herodotus and Thucydides close to tragedy, Such operact (see Flaig vol.). In a genre deemed especially typical of Ath with a plurality of voices, and the form tragedy too, the audience is confronted with a plurality of voices, and of drama even eliminates the secure guidance offered by a narratorial voice. Furthermore, what Greek tragedy contributes to the political life of Athens is not the presentation of clear-cut positions but the careful examination of issues from 
various perspectives (Meier 1993; Boedeker and Raaflaub 2005). Tragedy provides few answers but rather creates tensions and raises questions.

This perspective highlights in Herodotus and Thucydides a discrepancy between form and content. Their critical view of democracy is expressed in a discourse that has at least some affinity with democracy. Of course, this thesis leaves aside impor tant aspects and dangerously simplifies complex matters. Particularly in Herodotus there are passages that yield a more positive idea of democracy, while in assessing Thucydides' narrative we need to take into account that it is presented by a rather strong narrator. Yet the discrepancy between form and content for which $I$ have argued can be supported by examining a parallel that I find rather striking: the Platonic dialogues.

Plato not only ranks prominently among the "enemies of the open society" (Popper 1945) but he resembles especially Thucydides in his critique of rhetoric in democracy (Yunis 1996; Ober 1998). This parallel can be extended even further. I have argued that speeches are embedded in the History as a foil to the historian's approach to the past. A very similar case has been made for Plato. In her book "Genres in Dialogue" (1995), Andrea Nightingale demonstrates that Plato integrates other genres into his dialogues in order to define his own work. One of these genres is oratory. Particularly praise speeches figure in the dialogues as foils. Of course, there are differences between what Thucydides and Plato set agains rhetoric - for example, the philosopher's concept of truth differs greatly from the historian's claim to veracity - but it is striking that two new genres try to establish a place for themselves by criticizing rhetoric both explicitly and implicitly.

The integration of other genres illustrates the polyphonous nature of Platonic dialogue. Even more than in the History and Histories, the readers of the dialogues are confronted with ambiguities and forced to construct meaning themselves. In some of Plato's works, it is easy to see in Socrates an authoritative figure that leads the readers; here the conversation merely seems to serve the purpose of bringing the interlocutors to accept Socrates' own view. Yet things are often more complex than this, and other dialogues leave no doubt about the openness of the issues at stake.

In a "provocative essay" (Barber 1996: 361), Peter Euben argues for parallels between the dialectic in Plato's dialogue and in democracy (1996; see also Monoson 1994; Saxonhouse 1996: 87-114). There are clearly limits to this comparison - in his response to Euben, Barber (1996) contrasts Plato's foundationalist philosophy to the anti-foundationalist politics of democracy - and Euben's attempt to transform Plato into a democratic thinker may not be convincing in the end, but he does point out an affinity between the Platonic dialogue and democratic discourse. If, while following this argument, we do not neglect Plato's explicit criticism of democracy, a discrepancy between form and content comes to the fore, and it is very similar to that which we have detected in Herodotus and Thucydides. Historiography and philosophical dialogue not only emerged in democracy as new critical prose genres, but democracy itself provided them with the discursive means needed for criticism of itself. There is, however, another - rather bold - way of viewing this constellation: not even the "enemies" another - rather bold - way of evade its influence; even the critique of democracy was of democracy were able to discourse.

steeped in democratic discourse. Bakhtin and his circe (1981: 3-40,259-422). According to this view, the form as forms of knowledge (1981. $3-40,259-422)$. Aistoriography and Platonic dialog and content of genres determine one another. Historiograch. Both can be analyzed afford two very interesting cases for a Bakhtimian intellectual and political history. fruitfully against the backdrop of contemporary intellectual and political history Yet, their relation to democracy is rather complex and built on a discrepancy between form and content: while engaging in critical discussions with democratic ween form and content: while engaging in criticism taps into resources that are essentially views, their
democratic.

\section{Abbreviations}

GRBS Greek, Roman, and Byzantine Studies

ISJ Liddell, H. G., R. Scott, and H. S. Jones (eds.). 1968. A Greek-English Lexicon. 9th ed.

PMG Poetae Melici Graeci. Ed. D. L. Page. Oxford, 1962.

Realencyclopädie der classischen Altertumswissenschaft

\section{Notes}

All dates are BCE. The translations of Herodotus and Thucydides are based on de Al dites an Sélincourt and Marincola 2003 and Lattinore 1980 . In $\mathrm{I}$ have used some of its material ter was presented took place

Bet $1995 \cdot 540-2$. Meier's distinction is based on the shift in constitutional terminology from words based on nomos (order) to those the shift in constitutional terner, rule); sce Meier 1990: ch.7

Morris 1996 (see 2000: pt.3); Raaflaub and Wallace 2007 strongly emphasize the archaic Morris 1996 (see 2000: pt.3), Ranlu democracies outside of Athens, sce Robinson 1997. roots of classical democracy; on early democracies outside ox texts: Raaflaub 2000. Hammer Accordingly, political reflections can be found implications of the Homeric epics.

2002 , for example, demonstrates the political implications of the Heginning of the Iliad with its long chain of causes

4. It may suffice here to mention the beginning of the Iliad with its long chain of causes responsible for the wrath of Achilles.

On Herodotus and Athens; see. Moles 2002; on Thucydides and Athens, Raaflaub 2006

On entar in On the past in the epinphioi or in oratory in general, Schroeder 1914; Pearson 1941; on the past in other speeches or in oratory in 2001; Clarke 2008: 245-303; Grethlein Perlman 1961; Nouhaud 1982,

2010: 126-45; Steinbock (2012).

7 See Curtius 1886; Jacoby 1949: $134 \mathrm{n.28}$; Bux 1960; von Fritz 1967.337-47.

8 See LSJ s.p. agōn $\operatorname{\text {III}} 4$. In the History, see Cleon's critique of political oratory as agonistic in $3.38 .3-4$ 
9 Scholarship on the speeches found in 'Thucydides' History has focused either on the question of their authenticity or on their relation to the narrative. For the first, see Hornblower 1987: 45-72 and Garrity 1998 with further literature; for the second, see de Romilly 1956; Hunter 1973; Stahl 2003. See also the articles in Stadter, 1973 . In this chapter, I outline another approach that can be dubbed "metapoctic" because, in reading speeches as foils to the History, I interpret them as a commentary on the work itself.

10 For a more detailed interpretation, sec Grethlein 2005, 2010:221-8. Pericles' Funeral Oration has been interpreted in many different ways. The traditional reading sees it as a eulogy of Athens (see Landmann 1974 and the literature in Gaiser 1975: 19 n.10). On the other hand, Flashar 1969 elaborates on the tensions between Athens as presented in this speech and the History's narrative. Sicking 1995 and Bosworth 2000 try to interpret the speech in its historical context.

li On Thucydides' criticism of the rhetoric of Pericles' successors, see Yunis 1996: 87-116. See also Ober 1998: 79-94.

12 For the Sicilian expedition, see. Thuc. 6.1.1 with Stahl 2003: 8; Kallet 2006; for the digression on the tyrannicide, see Thuc. 6.60.1 with Ober 1998: 105-6; Kallet 2001: 31; Grethlein 2010: 214-20. For discussion of 'Thucydides' claim of Athenian igno rance of Sicily, which the historian exaggerates greatly, see Ober 1993; Smith 2004.

13 On links between Thucydides' account of the Peloponnesian War and Herodotus Histories, see Strasburger 1982: 757-58; Pelling 1991; Hornblower 1992; Moles 1993: 98-114; Scanlon 1994; Rood 1999; Raflaub 2002; Rogkotis 2006.

14 This conflict contrasts with the role of Chileos, a Tegean, who not much earlier had convinced the Spartans to answer the Athenians' request for help (9.9).

15 My interpretation does not depend on the question of whether the debate was historical; for an argument against its historicity, see already Maass 1887: $589 \mathrm{nn}$.1. What is impor tant is that the argumentative strategics are typical of speeches at that time. For the use of the past in oratory, see n.6 above.

16 See Pallantza 2005: 167-8. On the central role of Marathon in the Athenians' speech, see also Solmsen 1944: 249

17 On the intricacies of exempla in Herodotus and Thucydides and a comparison with the modern skepticism about exemplary thinking, see Grethlein 2011 a

18 See the literature listed in n.6.

19 Sce, for example, Meyer 1899: 219-21; Jacoby 1913: 491; Schmitz-Kahlmann 1939: 63-5; Solmsen 1944: 249; West 1970: 275; Loraux 1986: 65. Kierdorf 1966: 107 makes the interesting argument that the canon of mythical deeds was not formed through the funeral speeches, but derives from speeches about foreign affairs. For more on this link, see also the literature cited by West 1970: 274 n.16.

20 Cf. Schulz 1933: 40; Kierdorf 1966: 98. Moreover, the reference to the Trojan War distinguishes the Athenian speech from the preserved epitaphioi logoi, only two of which mention the Trojan War, yet never as a part of the catalogue of deeds (Demosthenes 60.10-11 and Hyperides 6.35-6); see Gotteland 2001: 218. Kierdor 1966: 98-9 argues that the reference to the Trojan War is a relic from propaganda used before the Persian Wars.

21 There are further similarities, such as the antithesis between word and deed (logos ergon) in 9.27.1, which, of coursc, is widespread in Greek literature but has particular prominence in the funeral specches.
22. The parallel between the Amazon invasion and the Persian attack is even marked: according to the Athenians' speech, the Amazons came from the river Thermidon (9.27.4) and later the Persians are said to come from the same river $(9.43 .2)$

3 Cf Kierdorf 1966: 109: "Die Athenerrede bei Herodot ist insofern ein wenig anachronistisch, als sie die mythischen Parallelen (Hikesie-Geschichte) zu einem Ereignis bietet, das sich zu der angenommenen Zeit noch gar nicht ereignet hat." See also Munson 2001: 220, who notes that the speech "conforms to the manner of fifth-century hegemonic rhetoric."

24. 9.26.4: hēgemona; 26.5 and 26.6: hëgemoneuein; 27.6 : stasiazein.

5. Hdt 9.73.3. For later ancient testimonies, see Macan 1908: ad 9.73.2; also Mills 1997: $7-10$.

26. Flower and Marincola 2002: at 9.73.2. If Theseus was indeed presented as a mirror for Pericles, this would have a parallel in Thucydides; see Walker 1995: 195

27 On the foreshadowing of later intra-Hellenic conflicts in the Histories, cf. Fornara 1971. Cobet 1971: 114-16; Raaflaub 1987; Stadter 1992; Moles 2002: 48-52. Strasburger 1982 emphasizes .Herodotus's critical view of Athens. Yet the relation Herodotus establishes between the Persian Wars and later Greek conflicts is more Herodotus establishes between the Persian wirst Sicilian complex. Raaflaub 2002: 21 forcefully argues that the experience of the first Sicilian
expedition (427-24) provided crucial inspiration for Herodotus's interpretation of the Persian invasion of Greece.

28 For a discussion of the reception of Plataea in antiquity, see now Jung 2006: 225-383 with further literature. Another act of commemoration that could be interpreted as alis' attempt to appropriate Plataea for itself is Simonides' "Plataea elegy." What a polis" at in tow a surives of it sho 2001: 102-4). Yet, there are also aspects that imply a Pan-Hellenic perspective, and the orientation of the whole poem is a hotly debated subject (see, e.g., Boedeker and Sider 2001).

29 Cf. Grethlein 2005: 69. On the influence of contemporary rhetoric on Herodotus, see Jacoby 1913: 333; Aly 1969: 286-96; on the strong rhetorical shaping of Thucydides History sec Moraux 1954; Connor 1984: 6, 27-8; Woodman 1988: 5-69; Tsakmakis 1998

Reader-response-thcory points out that any reader of any text constructs meaning herself. Yet, depending on the openness of texts, the "act of reading" can be variously intense. Some texts, such as the Histories or History, reinforce the involvement of their readers.

\section{References}

Aloni, A. 2001. "The Proem of Simonides' Plataea Elegy and the Circumstances of Its Performance." In Boedeker and Sider 2001: 86-105.

Aly, W. 1969. Volksmärchen, Sage und Novelle bei Herodot und seinen Zeitgenossen. Ein Untersuchung über die volkstïmlichen Elemente der altgriechischen Prosaerzähblung.

2nd ed. Göttingen.
Bakhtin, M. M. 1981. The Dialogic Imagination. Austin.

Barber, B. R. 1996. "Misreading Democracy: Peter Euben and the Gorgias." In Ober and Hedrick 1996: 36I-76. 
Bleicken, J. 1995. Die athenische Demokratie. 4th ed. Paderborn.

Boedeker, D. 1995. "Simonides on Plataea: Narrative Elegy, Mythodic History." Zeitschrif fiur Payrologie und Epigraphik 107: 217-29.

Boedeker, D. 2012. "Speaker's Past and Plupast; Herodotus in the Light of Elegy and Lyric." In Grethlein and Krebs 2012: 17-34.

Boedeker, D. and D. Sider (eds.). 2001. The New Simonides: Contexts of Praise and Desire Oxford.

Boedeker, D. and K. Raaflaub. 2005. "Tragedy and City." In R. Bushnell (ed.), A Companion to Tragedy, 109-27. Malden MA and Oxford.

Bosworth, A. B. 2000. "The Historical Context of Thucydides' Funeral Oration." Journal of Hellenic Studies 120: $1-16$.

Burzacchini, G. 1995. "Note al nuovo Simonide." Eikasmos 6: 21-38.

Bux, E. 1960. "Logographen.” RE XIII.I: 1021-27.

Clarke, M. 2008. Making Time for the Past Local History and the Polis Oxford.

Cobet, J. 1971. Herodots Exkurse und die Frage der Einheit seines Werkes. Wiesbaden.

Connor, W. R. 1984. Thtucydides. Princeton.

Creuzer, G. F. 1845. Die historische Kunst der Griechen in ihrer Entstebung und Fortbildung. 2nd ed. Leipzig.

Curtius, G. 1886. "Ueber zwei Kunstausdrücke der griechischen Literaturgeschichte," In Curtius, Kleine Schriften, II: Ausgewählte Abbandlungen wissenschaftlichen Inbalt 239-54. Ed. E. Windisch. Leipzig.

Euben, J. P. 1996. "Reading Democracy: 'Socratic' Dialogues and the Political Education of Democratic Citizens." In Ober and Hedrick 1996: 327-60

Flashar, H. 1969. Der Epitaphios des Perikles. Seine Funktion im Geschichtsserk des Thukydides Heidelberg.

Flory, S. 1990. "The Meaning of tò mythödes (I.22.4) and the Usefulness of Thucydides" History." Classical Journal 85: 193-208.

Flower, M. A and J. Marincola (eds, comm. . 2002. Herodotus, Histories Book IX. Cambridge. Fornara, C. W. 1971. Herodotus. An Interpretative Essay. Oxford.

Fowler, R. L. 1996. "Herodotos and His Contemporaries." Journal of Hellenic Studies 116 $62-87$

Fritz, K. von. 1967. Die griechische Geschichtsschreibung, I. Berlin.

Gaiser, K. 1975. Das Stantsmodell des Thuky,dides, Zur Rede des Perikles fiur die Gefallenen. Heidelberg.

Garrity, T. F. 1998. "Thucydides 1.22.1: Content and Form in the Speeches." American Journal of Philology 119: 361-84

Gotteland, S. 2001. Mythe et rhétorique. Les exemples mythiques dans le discours politique de l'Athènes classique. Paris.

Grethlcin, J. 2004. "Logographos und Thuc. 1.21.1." Prometheus 30: 209-16.

Grethlein, J. 2005. "Gefahren des logos. Thukydides' 'Historien' und die Grabrede des Perikles." Klio 87: 41-71

Grethlein, J. 2006. "The Manifold Uses of the Epic Past. The Embassy Scene in Hdt. 7.1 53-163." American Journal of Philology 127: 485-509.

Grethlein, J. 2010. The Greeks and their Past. Poetry, Oratory and History in the Fifth Century $B$ BE. Cambridge.

Grethlein, J. 201 la. "Historia Magistra Vitae in Herodotus and Thucydides? The Excmplary Use of the Past and Ancient and Modern Temporalities." In A. Lianeri (ed.), The Western
Time of Ancient History. Historiographical 247-63. Cambridge.

Grethlein, J. 2011b. "The Rise of Greek

Giethlein,

A. Feldh.

Grethlein, J. 2012. "The Use and A"

and Krebs 2012: 57-75.

Grethlein, J. and C. Krebs (eds.

'plupast' from Herodotus to Apt

The Iliad as Polit

Hammer, D. 2002. Th Thudides. Baltimo

Hornblower, S. 1987. "The Religious Dimen

Hornblower, S. 1992. "The Religious Dimen.

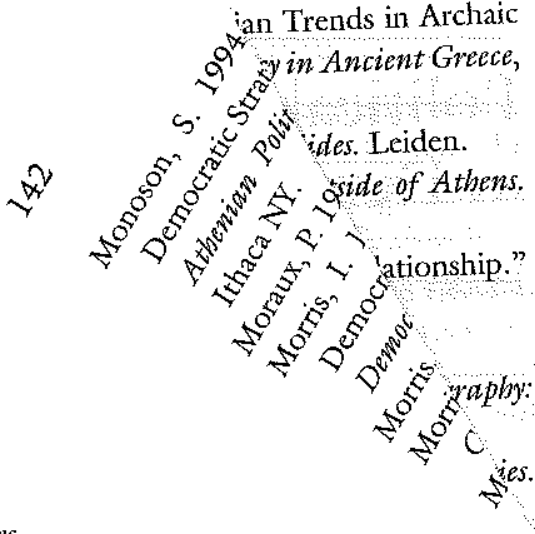

Thucydides Does Not Tell Us." Harful Reporter. Toro

Hunter, V. 1973. Thucydides: The Artful Repo 205-520.

Jacoby, F. 1913. "Herodotus." RE Supp. II: 205-520. Athens. Ox

Jacoby, F. 1949. Atthis: The Local Chronicles of Ancient Athens. Ox. "lin.

Jung, M. 2006. Marathon und Plataiat

antiken Griechenland. Göttingen.

its Aftermath. Berkeley.

Kallet L. 2006 "Thucydides' Workshop of History and Utility outside the Text.

In Rengakos and Tsalmakis 2006: 335-68.

Kennedy G. 1963. The Art of Persuasion in Greece. Princeton.

Kerersellung der Perserkriege. Göttingen.

Kerdorf, W. 1966. landmann, G. T. 1974. "Delveticum 31: 65-95.

34-41)." Musetum Helveticum 31. 65-95. Peloponnesian War. Indianapolis.

Lattimore, S. (trans.). 1998. Thucydides. The Peloponnesian.

Lipsius, J. H. 1886. Quatestiones logographicae. Leipzig. Loraux, N. 1986. The Invention of Athens: The Funeral Oration in the Classical Ciby. Trans. A. Sheridan. Cambridge MA.

A. "Weschichte der griechischen Prosa." Hermes 22 Mas6-95. 566-95.
Macan, R. W. (comm.). 1908. Herodotus: The Seventh, Eighth, and Ninth Books, 2 vols.

London.

Meier, C. 1980. Die Entstelung des Politischen bei den Griechen. Frankfurt am Main.

Meier, C. 1987. "Historical Answers to Historical Questions: The Origins of History in (Avethusa 20),

41-57. Baltimore. Meier, C. 1990. The Greek Discorory frek Tragedy. Trans. A. Webber. Baltimore.

Meier, C. 1993. The Political Art of Greek Tragedy. Te, II: Zur Geschichte des 5. Jbs. 1. Chr. Meyer, $\mathrm{E}$

Mills, S. 1997. Theseus, Tragedy, and the Atbenian Empire. Oxford.

"Truth and Untruth in Herodotus and Thucydides." In C. Gill and

1. P. Wiseman (eds.), Lies and Aiction in th E. J. Bakker, I. J. F. De Jong, and H. van Wees (eds.), Brill's Companion to Herodotus, 33-52. Leiden. 
Time of Ancient History. Historiographical Encounters with Greek and Roman Pasts, 247-63. Cambridge.

ilegy and

nd Desire.

ompanion

"Journal

Grethlein, J. 2011b. "The Rise of Greek Historiography and the Invention of Prose." In

A. Feldherr and G. Hardy (eds.), The Oxford History of Historical Writing, I: 148-70.

Oxford.

Grethlein, J. 2012. "The Use and Abuse of History in the Plataean Debate." In Grethlein and Krebs 2012: 57-75.

Grethlein, J. and C. Krebs (eds.). 2012. Time and Narrative in Ancient Historiography: The 'Plupast' from Herodotus to Appian. Cambridge.

Hammer, D. 2002. The Iliad as Politics: The Performance of Political Thought. Norman.

Homblower, S. 1987. Thucydides. Baltimore.

Hornblower, S. 1992. "The Religious Dimension to the Peloponnesian War, Or, What

Thucydides Does Not Tell Us." Harvard Studies in Classical Philology 94: 169-97.

Hunter, V. 1973. Thucydides: The Artful Reporter. Toronto.

ten.

Jacoby, F. 1913. "Herodotus." RE Supp. II: 205-520.

Jacoby, F. 1949. Atthis: The Local Chronicles of Ancient Athens. Oxford.

Jung, M. 2006. Marathon und Plataiai. Zwei Perserschlachten als "lieux de mémoire" im antiken Griechenland. Göttingen.

Kallet, L. 2001. Money and the Corrosion of Power in Thucydides: The Sicilian Expedition and its Aftermath. Berkeley.

Kallet, L. 2006. "Thucydides' Workshop of History and Utility outside the Text." In Rengakos and Tsakmakis 2006: 335-68.

Kennedy, G. 1963. The Art of Persuasion in Greece. Princeton.

Kierdorf, W. 1966. Erlebnis und Darstellung der Perserkriege. Göttingen.

Landmann, G. P. 1974. "Das Lob Athens in der Grabrede des Perikles (Thukydides II 34-41)." Museum Helneticum 31: 65-95.

Lattimore, S. (trans.). 1998. Thucydides. The Peloponnesian War. Indianapolis.

Lipsius, J. H. 1886. Quastiones logographicae. Leipzig.

Loraux, N. 1986. The Invention of Athens: The Funeral Oration in the Classical City. Trans. A. Sheridan. Cambridge MA.

Maass, E. 1887. "Untersuchungen zur Geschichte der griechischen Prosa." Hermes 22: 566-95.

Tefallenen.

American

alitique de

brede des

1 Hdt. 7.1

Macan, R. W. (comm.). 1908. Herodotus: The Seventh, Eighth, and Ninth Books, 2 vols. London.

Meier, C. 1980. Die Entstelung des Politiscben bei den Griechen. Frankfurt am Main.

Meier, C. 1987. "Historical Answers to Historical Questions: The Origins of History in Ancient Greece." In D. Boedeker, Herodotus and the Invention of History (Arethusa 20), 41-57. Baltimore.

Meier, C. 1990. The Greek Discovery of Politics. Trans. David McLintock. Cambridge MA. Meicr, C. 1993. The Political Art of Greek Tragedy. Trans. A. Webber. Baltimore.

Meyer, E. 1899. Forschungen zur Alten Geschichte, II: Zur Geschichte des 5. Jhs. v. Chr. Halle.

Mills, S. 1997. Thesets, Tragedy, and the Athenian Empire. Oxford.

Molcs, J. 1993. "Truth and Untruth in Herodotus and Thucydides." In C. Gill and T. P. Wiseman (eds.), Lies and Fiction in the Ancient World, 88-121. Austin.

Moles, J. 2002. "Herodotus and Athens." In E. J. Bakker, I. J. F. De Jong, and H. van Wees (eds.), Brill's Companion to Herodotus, 33-52. Leiden.

Published in:

The Greek Polis and the Invention of Democracy: A Politico-cultural Transformation and Its Interpretations Johain P . Arnason (Editor), Kurt A. Raaflaub (Editor), Peter Wagner (Editor) 
Monoson, S. 1994. "Frank Speech, Democracy, and Philosophy. Plato's Debt to a Democratic Strategy of Civic Discourse "In J. P. Euben, J. R. Wallach, and J Ober (eds.), Athenian Political Thought and the Reconstruction of American Democracy 172-97. Ithaca NY

Moraux, P. 1954. "Thucydide et la rhétorique." Les études classiques 22: 3-23.

Morris, I. 1996. "The Strong Principle of Equality and the Archaic Origins of Greek Democracy." In J. Ober and C. Hedrick (eds.), Démokratia: A Conversation on Democracies, Ancient and Modern, 19-48. Princeton.

Morris, I. 2000. Archaeology as Cultural History. Malden MA and Oxford.

Morrison, J. V. 1999. "Preface to Thucydides. Rereading the Corcyrean Conflict (1.24-55)." Classical Antiquity 18: 94-131.

Munson, R. V. 2001. Telling Wonders: Ethnographic and Political Discourse in the Work of Herodotus. Ann Arbor.

Neumann, U. 1995. Gegenwart und mythische Vergangenheit bei Euripides. Stuttgart.

Nightingale, A. W. 1995. Genres in Dialogiue: Plato and the Construct of Philosophy'. Cambridge.

Nouhaud, M. 1982, L'utilisation de l'histoire par les orateurs attiques. Paris.

Ober, J. 1993. "Thucydides' Criticism of Democratic Knowledge." In R. M. Rosen and J. Farrell (eds.), Nomodeiktes: Greek Studies in Honor of Martin Ostwald, 81-98. Ann Arbor:

Ober, J. 1998. Political Dissent in Democratic Athens: Intellectual Critics of Popular Rule. Princeton.

Per I. and C. Hedrick (eds.). 1996. Dēmnokratia: A Conversation on Demnocracies, Ancient and Modern. Princeton.

Pallantza, E. 2005. Der Troische Krieg in der nachbomerischen Literatur bis zum 5. Jh. v. Chr Wiesbaden.

Pearson, L. 1941. "Historical Allusions in the Orators." Classical Philology 36: 209-29.

Pelling, C. B. R. 1991. "Thucydides' Archidamus and Herodotus' Artabanus." In

M. A. Flower and M. Toher (eds.), Georgica: Greek Studies in Honour of George Cawkwell, 120-42. London.

Perlman, S. 1961. "The Historical Example, its Use and Importance as Political Propaganda in the Attic Orators." Scripta Hierosolymitana 7: 150-66.

Popper, K. R. (1945). The Open Society and its Enemies. 2 vols. London.

Porciani, L. 2001. Prime forme della storiografia greca. Prospettiva locale e generale nello narrazione storica. Stuttgart.

Raaflaub, K. 1987. "Herodotus, Political Thought, and the Meaning of History." In D. Boedeker (ed.), Herodotus and the Invention of History, 221-48. Arethusa 20.

Raaflaub, K. 2000. "Poets, Lawgivers, and the Beginnings of Greek Political Reflection." In

C. Rowe and M. Schofield (eds.), The Cambridge History of Greek and Roman Political Thought, 23-59. Cambridge.

Raaflaub, K. 2002. "Herodot und Thukydides. Persischer Imperialismus im Lichte der athenischen Sizilienpolitik." In N. Ehrhardt and L.-M. Günther (eds.), Widerstand Anpassung - Integration. Die griechische Staatenwelt und Rom (Festschrift J. Deininger) 11-40. Stuttgart.

Raaflaub, K. 2006. "Thucydides on Democracy and Oligarchy." In Rengakos and Tsakmakis 2006: $189-222$.
Raatlaub, K. and R. W. Wallace. 2007. "People's Power and Egalitarian Trends in Archaic Greece." In Raaflaub, J. Ober, and R. W. Wallace, Origins of Democracy in Ancient Greece, 22-48. Berkeley.

Takmakis (eds.). 2006. Brill's Companion to Thucydides. Leiden.

Rengakos, A., and A. Tsakmakis (eds.). 2006. Bril Popular Government Outside of Athens. Robinson, E.

Stuttgart. 2006 "Thucydides and Herodotus: Aspects of Their Intertextual Relationship." Rogkotis, Z. 2006. Tsakmakis 2006: 57-86.

In Rengakos and Tsakmakis 2006: $57-86$.

Romilly, J. de. 1956. Histoire et raison chez Thucydide. Paris. The Limits of Historiography.

Rood, T. 1999. “Thucydides' Persian Wars." In C. S. Kraus(cd.), The Lim

Genre and Narrative in Ancient Historical Texts, Saxonhouse, A

Notre Dame. canlon, T. 1994. "Ectoria 43: 143-75.

Law." Historia 43. 143-75. Schmitz-K

Leipzig.

1914. De laudibus Athenarum a poetis tragicis et ab oratoribus epidicticis excultis. Göttingen.

Schulz, E. 1933. Die Reden im Herodot. Greifswald.

Selincourrt, A. de, and "The General Purport of Pericles' Funeral Oration and Last Speech."

Hicking, C. M. J. 1995. “The

Smith, D. F. 2004. "Thucydides' Ignorant Athenians and the Drama of the Sicilian Expedition." Syllecta Classica 15: 33-70.

" 1944. "Speeches in Herodotus' Account of the Battle of Plataea." Classical Pbilology 39: 241-53.

Stadi

Stadter, P. A. (ed.). "Herodotus and the Athenian Arche." Annali della Scuola Normale Stadter, P. A. 1992. "Herodotus and the A

Superiore di Pisa, 3rd ser. 22: 781-809. Stahl, H..P. 2003. Thucydides: Man's Place in History. Swansca.
Steinbock, B. (2012). Social Memory in Athenian Public Discourse: Uses and Meanings of the Past Michigan.

Strasburger, H. 1982. "Herodot und das perikleische Athen." In Strasburger, Studien zu Strasburger, Ho 198. Hildesheim. Alten Geschichte, "Von der Rhetorik zur Geschichtsschreibung. Das 'Methodenkapitel' Tsakmakis, A. 1998. "Von der." Rheinisches Musseum 141: 239-55.

des Thukydides (1,22,1-3)." Rheinisches Museum 141: 239-55. West, W. C. 1970. "Saviors of Greece." Greek, Roman,

Walker, H. J. 1995. Theseus and Athens. New York.

Woodman, A. J. 1988. Rhetoric in Classical Historiograpby: Four Studies. London.

Woon 1996 Taming Democracy: Models of Political Rhetoric in Classical Athens. Ythaca N 